九病虫研会報 $38: 32-35$ (1992)

Proc. Assoc. Pl. Prot. Kyushu 38 : 32-35 (1992)

\title{
ジエトフェンカルブ剤とべノミル剤に耐性を示す 灰色かび病菌の発生
}

尾松 直志・和泉 勝一 (鹿児島県農業試験場)

\begin{abstract}
Occurrence of Botrytis cinerea resistant to diethofencarb and benomyl fungicides. Naoshi OMATSU and Shoichi IZUMI (Kagoshima Agricultural Experiment Station, Kagoshima 891-01)
\end{abstract}

灰色かび病のベンズイミダゾール系薬敵耐性菌は全国 的に発生し，鹿児島県においてもほとんどの果菜類で高 率に発生して防除上大きな問題になっている”。近年, ベンズイミダゾール系薬骫耐性菌に対して負の交差耐性 を示すジェトフェンカルブ棛が開発され，本郕混合㘊が 防除に利用されるようになり高い防除効果が期待できる ようになった1.3.4)。1991年に本県における灰色かび病薬 棛耐性菌発生調查を実施したところ，イチゴ围場からべ

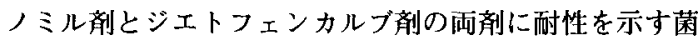
株が分離された。この菌株の培地上での性質と病原性に ついて調查を行ったので報告する。

\section{材 料 及び 方 法}

灰色かび病薬㘊耐性菌発生調査は，1991年 3 月から 5 月に罪病果を探集し常法に従って実施し，ベノミル100 $\mathrm{ppm}$, ジエトフェンカルブ $100 \mathrm{ppm}$, イプロジオン 500 ppmで菌系が伸長した菌株を耐性菌とみなした。灰色 かび病菌の培地上での性質と病原性の調查には，イプロ ジオン鼡には感受性を示すがベノミル骩とジエトフェン カルブ棛の両郕に耐性を示す菌株（RSR 菌）と，イチ ゴ、エンドゥから分離したベノミル郕とイプロジオン郕 に感受性でジェトフェンカルブ骩に耐性を示す菌株 (SSR 菌)，ベノミル剤に耐性を示しイプロジオン骩と ジェトフェンカルブ剤に感受性を示す菌株（RSS 菌） を用いた。なお，これらの菌株はいずれも単菌系分離を 3 回繰り返したものをPSA 斜面培地に保存して実験に 供した。

\section{1）薬剤感受性の検定}

検定にはベンレート水和剤（䑾品，50\%），ロブラー

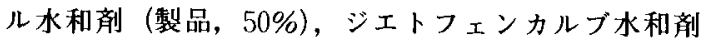
(製品，25\%) を用いて成分量で，0，1，2.5，5，10， $25 ， 50 ， 100 ， 200 ， 400 ， 800 ， 1600 ， 2400 \mathrm{ppm}$ に調整 した PSA 培地平板を検定培地として用いた。PSA 培
地上で $25^{\circ} \mathrm{C} ， 4$ 日間前培養した菌叢の先端部分を径 $4 \mathrm{~mm}$ の disk に切抜き，検定培地に置床し， $25^{\circ} \mathrm{C} て ゙ 2$ 日間培 養して菌系の生育の有無を調查し, 最小生育阻止莀度 (MIC) を求めた。

\section{2）菌系生育量}

PSA 平板培地で 4 日間培養した菌叢の先端を径 $4 \mathrm{~mm}$ の disk に切抜き PSA 平板培地に置床し， 5，10，15， $20,25,27,30,33,35^{\circ} \mathrm{C}$ の恒温器でそれぞれ48時間培 養後, 菌叢の伸長量（菌丵の最大直径一disk の径）を 测定した。

\section{3）PSA 培地上における分生胞子，菌核の形成}

菌系生育量調查と同様に各温度下で培養し, 分生胞子, 菌核の形成状況を調查した。

\section{4）病原性の検定}

キュウリ果実を長さ $5 \mathrm{~cm}$ に切り, PSA培地平板で $25^{\circ} \mathrm{C}$ で 4 日間培養した菌丵上に立て，25 $\mathrm{C}$ 下におき，4 日後に果実の病斑長を測定した5)。またその後の果実上 に抢ける分生胞子の形成状況を肉眼で観察した。<smiles>[Mg][Mg]</smiles>

1991年 3 月〜 5 月に, イチゴの 6 围場292菌株, エン ドゥ 2 戋場74菌株, インゲン 4 戋場221菌株の灰色かび 病菌について, 薬郕感受性の検定を行ったところ, イチ ゴの 1 固場から, ベノミル 100 ppm とジェトフェンカル ブ100 ppm の双方で菌系が生育する菌株が検出された (第 1 表)。本菌株（RSR2-16 菌株）のベノミルに対す る感受性はべノミル耐性菌と同様に MIC で $1600 \mathrm{ppm}$ を示し，またジエトフェンカルブに対する感受性はべ， ミル感性菌と同様に MIC で $2400 \mathrm{ppm}$ を示した（第 2 表)。このようにRSR2-16 菌株はべノミルとジエトフ エンカルブの両刘に高度の耐性を有したが，イプロジオ ンに対しては感受性であった。RSR2-16 菌株の PSA 培地上に捛ける菌系生育は他菌株と比べいずれの温度段 
第 1 表 鹿児岛におけるイチゴ固場から操集した灰色かび 病菌の種類別薬剤耐性菌の出現頻度

(1991年)

\begin{tabular}{|c|c|c|c|c|c|}
\hline \multirow{2}{*}{$\begin{array}{l}\text { 調查 } \\
\text { 直場 }\end{array}$} & \multirow{2}{*}{ 探集時期 } & \multirow{2}{*}{$\begin{array}{l}\text { 検 定 } \\
\text { 菌株数 }\end{array}$} & \multicolumn{3}{|c|}{ 薬商耐性菌種類別菌株数 } \\
\hline & & & RSS 菌 & SSR 菌 & RSR 菌 \\
\hline \multirow{3}{*}{ A } & 3.11 & 14 & $4(28.6)$ & $10(71.4)$ & 0 \\
\hline & 3.28 & 20 & $3(15.0)$ & $17(85.0)$ & 0 \\
\hline & 4.16 & 25 & $1(4.0)$ & $24(96.5)$ & 0 \\
\hline \multirow{4}{*}{ B } & 3.11 & 19 & 0 & $19(100)$ & 0 \\
\hline & 3.28 & 21 & $1(4.8)$ & $19(90.4)$ & $1(4.8)$ \\
\hline & 4.16 & 22 & 0 & $22(100)$ & 0 \\
\hline & 5.13 & 22 & $1(4.6)$ & $21(95.4)$ & 0 \\
\hline \multirow{3}{*}{$\mathrm{C}$} & 3.11 & 18 & $2(11.1)$ & $16(88.9)$ & 0 \\
\hline & 3.28 & 12 & 0 & $12(100)$ & 0 \\
\hline & 4.16 & 20 & $1(10.0)$ & $18(90.0)$ & 0 \\
\hline \multirow{4}{*}{ D } & 3.11 & 20 & $2(10.0)$ & $18(90.0)$ & 0 \\
\hline & 3.28 & 5 & 0 & $5(100)$ & 0 \\
\hline & 4. 16 & 20 & $1(5.0)$ & $19(95.0)$ & 0 \\
\hline & 5.13 & 16 & $1(6.2)$ & $15(93.8)$ & 0 \\
\hline $\mathrm{E}$ & 3.13 & 16 & $2(12.5)$ & $14(87.5)$ & 0 \\
\hline $\mathrm{F}$ & 3.13 & 22 & $1(4.6)$ & $21(95.4)$ & 0 \\
\hline
\end{tabular}

注) RSS 菌：ベノミル剆にのみ面性を示す菌株

SSR 菌：ジェトフェンカルブ剂にのみ耐性を示す菌株

RSR 菌：ベノミル剂とジェトフェンカルブ郕の両片に耐性 を示す菌株
階でも劣り，特に低温側で劣る傾向がみられ，気中菌系 が多かった。また，他菌株はいずれも20ㄷ生育のピー クがみられたが, RSR2-16 菌株の生育のピークは $27^{\circ} \mathrm{C}$ で，他菌株に比べ高温性であった(第 3 表)。

PSA 培地上における培鉒13日後の胞子形成状況をみ ると，分生胞子を形成した温度は，イチゴから分離した 3 菌株は10 20ㄷで, エンドゥから分離した 2 菌株は 10 ～ $27^{\circ} \mathrm{C}$ だったか, RSR2-16 菌株は $15^{\circ} \mathrm{C}$ みで形成し, 分生胞子形成量も少なかった (第 4 表)。

PSA 培地上に括ける培養13日後までの菌核形成状況 をみると，イチゴ，エンドウから分嶣した他の 6 菌株は 菌核を形成したが RSR2-16 菌株では菌核形成は全く 見られなかった(第 5 表)。

キュウリ果実上の病斑の伸長程度で病原性を検討した 結果, RSR2-16 菌株はキュウリ果実に病原性を示した が他菌株と比べ病斑伸長が遅く病原性が弱いとみられた (第 1 図)。また RSR2-16 菌株の果実上での胞子形成 は，他菌株に比べて形成量が少ないことが認められた。 （）内は菌株率

第2表 薬戍耐性の異なる兏色かび病菌のベノミル，イプロジオン，ジエトフェンカルブに对する感受性

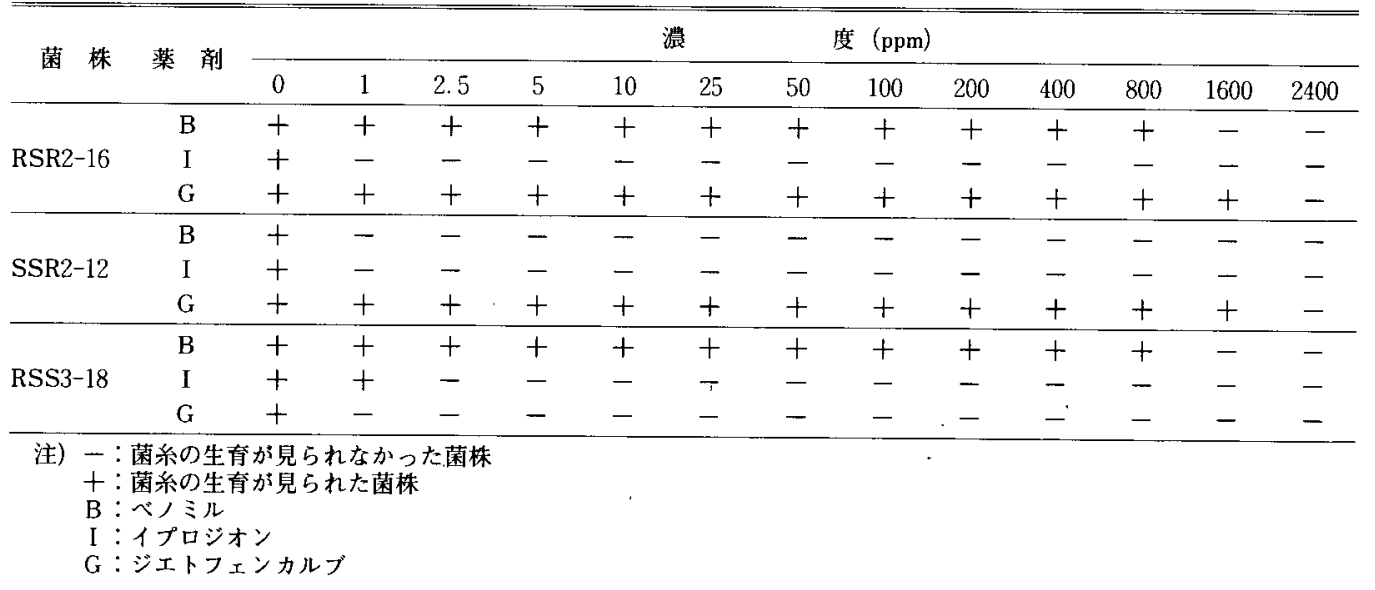

第 3 表 温度別菌系生育量の比較 (48時間後)

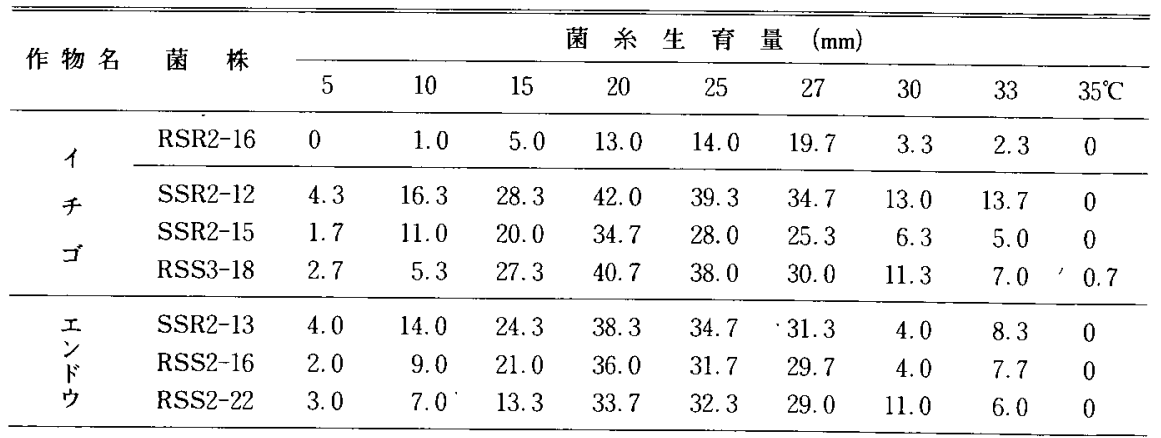

注）数值は菌叢の直径から $4 \mathrm{~mm}$ (接種菌の直径) を引いた数值 
第4 表 PSA 培地上における胞子形成程度（13日後）

\begin{tabular}{|c|c|c|c|c|c|c|c|c|c|c|}
\hline \multirow{2}{*}{ 作物名 } & \multirow{2}{*}{ 菌 株 } & \multicolumn{9}{|c|}{ 胞子形 成 程 度 } \\
\hline & & 5 & 10 & 15 & 20 & 25 & 27 & 30 & 33 & $35^{\circ} \mathrm{C}$ \\
\hline \multirow{4}{*}{$\begin{array}{l}\text { イ } \\
\text { チ } \\
\text { ゴ }\end{array}$} & RSR2-16 & - & - & + & - & - & - & - & - & - \\
\hline & SSR2-12 & - & + & + & + & - & - & - & - & - \\
\hline & SSR2-15 & - & + & + & + & - & - & - & - & - \\
\hline & RSS3-18 & - & + & + & + & - & - & - & - & - \\
\hline$x$ & SSR2-13 & - & - & - & - & - & - & - & - & - \\
\hline ン゙ & RSS2-16 & - & + & $H$ & $H$ & H & H & - & - & - \\
\hline ウ & RSS2-22 & - & + & + & H & H & H & - & - & - \\
\hline
\end{tabular}

注）：：胞子を形成しなかった。 十：胞子をすずかに形成した。 H：胞子を形成した。

第 5 表 PSA 培地上における菌核形成程度 (13日後)

\begin{tabular}{|c|c|c|c|c|c|c|c|c|c|c|}
\hline \multirow{2}{*}{ 作物 名 } & \multirow{2}{*}{ 菌 株 } & \multicolumn{9}{|c|}{ 菌 核 形 成 程 度 } \\
\hline & & 5 & 10 & 15 & 20 & 25 & 27 & 30 & 33 & $35^{\circ} \mathrm{C}$ \\
\hline \multirow{4}{*}{$\begin{array}{l}1 \\
f \\
\exists\end{array}$} & RSR2-16 & - & - & - & - & - & - & - & - & - \\
\hline & SSR2-12 & - & + & + & + & + & + & - & - & - \\
\hline & SSR2-15 & - & + & + & + & + & + & - & - & - \\
\hline & RSS3-18 & - & - & + & + & + & + & - & - & - \\
\hline \multirow{3}{*}{$\begin{array}{l}x \\
\text { V } \\
\qquad \\
ウ\end{array}$} & SSR2-13 & - & + & + & + & + & - & - & - & - \\
\hline & RSS2-16 & - & - & + & + & + & - & - & - & - \\
\hline & RSS2-22 & - & + & + & + & + & + & - & - & - \\
\hline
\end{tabular}

注) 一：菌核を形成しなかった。

+ ：菌核を形成した。

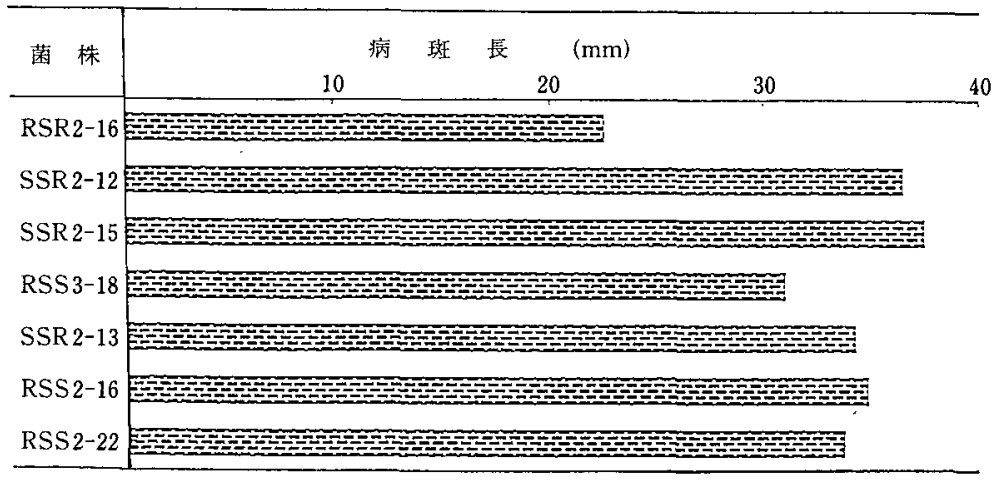

注）菌䇺上にに果実を固床 4 日後の病斑長

第 1 図キュウリ果実に対する灰色かび病菌の病原性

考、察

今回分離されたベンズイミダゾール系薬剤とジエトフ

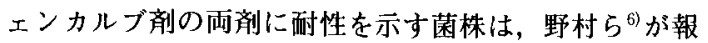
告した両片耐性菌と同じようにジカルボキシミド系薬郕
に感受性を示し，菌系生育が達く，病原性が弱い菌株で， しかも胞子形成量が少ないことが認められた。今回は1 チゴ，エンドウ，インゲンについて調查をおこなったが， このような菌株はイチゴの 1 圃場だけから，しかもその 戋場においても時期を違えて 4 回調查を行ったなかで一 
時期に 1 菌株のみ分離されたものでありここのような菌 株の存在は極めてまれであると考えられる。このような ことからこの菌株が急激に蔓延して防除上問題になるこ とは少ないと考えられる。しかしこの菌株が分離された 圃場は無防除に近い管理をしていたことから，自然界に はRSR 菌が存在していることを示唆していると考えら れる。またジエトフェンカルブ剂を連用し, ベンズイミ

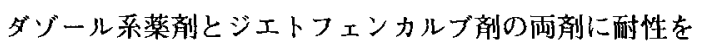
示す菌株が発生し実際に防除上問題になった報告”もあ る。今後はジエトフェンカルブ剤の使用の増加にともな って,このような両剤耐性菌が発生, 增殖することも考
えられ，薬骩耐性菌の発生動向は十分に注意していく必 要がある。

\section{引用文献}

1) 尾松直志. 和泉勝一- 鳥越博明（1991）九病虫研会報 37 : 15-20. 2) Katan, T., ELAD, D. and Yunis, H. (1989) Plant Path. 38：86-92. 3) 橗間善幸・三浦猛夫・日高 透・川越 仁（1989）九病虫研会報 $35: 37-40$. 4) 竹内妙子 (1991) 植物防疫 $45: 113-116$. 5) 手塚后夫・西泰道・渡 辺康正（1980）日植病報 $46: 26-33$. 6) 野村良邦・小林紀 彦（1991）日植病報 $56: 105$.

(1992年6月 1 日 受領) 